\title{
CURRENT IS PROGRAM CHALLENGES AND PROPOSED STRATEGIES TO ADDRESS THEM
}

\author{
Arnaldo I.Ramos-Torres, University of Puerto Rico,Arnaldo.Ramos1@upr.edu
}

\begin{abstract}
Information Systems (IS) programs are facing serious challenges. Some of them are external, therefore we can mostly react to them, while others are internal to our programs and consequently we can do a lot about them. It is very important for IS academics to be aware of these challenges, the implications they have, and the strategies that can be implemented to address them. Our contention is that the source of many challenges faced by IS programs is mostly internal, therefore the solution lies within. Experiential learning models, like Project-Based Learning (PBL), can make IS programs more responsive to student and industry needs, and also improve stakeholders' perception, therefore its potential to tackle some of the challenges. The continuous analysis and redefinition of the skill set that IS programs are developing in students also has a great potential to address these challenges.
\end{abstract}

Keywords: Information systems (IS), IS challenges, Project-based learning (PBL) and IS skill set

\section{INTRODUCTION}

Information Systems (IS) programs are facing challenges so serious that they are threatening the future of IS as an academic discipline. It is very important for IS academics to be aware of these challenges, the implications they have, and the strategies that can be implemented to address them.

The reduction in IS program enrollments, together with a perceived lack of relevance, are probably the main challenges being faced by these programs. But there are other important challenges as well. Some of them are related to the industry we are in, others are related to the way IS programs are externally perceived, and some are related to the internals of our programs.

This paper is the first one of a trilogy on how to address some of the challenges currently faced by Information System programs. It presents the main challenges faced by these programs, identifies strategies to deal with these challenges, and describes an implementation methodology for each strategy. Its main purpose is to contextualize empirical research that will be presented in subsequent papers on the implementation of the proposed strategies. Readers are encouraged to implement the strategies themselves and to assess results.

\section{INFORMATION SYSTEM CHALLENGES}

\section{Enrollment reduction}

Enrollment reduction, probably the main challenge being faced by IS programs, has been around for a time long enough to be simply attributed to a cyclical behavior in enrollments. Specific statistics for enrollment in IS programs are somewhat difficult to find in the literature. Many times these statistics are bundled with data about related programs, like Information Technology, Computer Science and Computer Engineering. But either separately or in conjunction with related programs, the statistics available show that there has been a decline in enrollments in the last decade. Several publications have presented and discussed this issue [14,11]. And yes, there seems to be a turnaround lately, mostly evidenced in Computer Science programs, but we are still far from the numbers we had in the 90's and early 2000's [22]. And if in fact there is a turnaround, we have to strengthen the conditions which gave rise to it, so that it does not represent just a small bounce in the enrollment curve. 


\section{Issues in Information Systems \\ Volume 14, Issue 2, pp.101-108, 2013}

\section{Loss of relevance}

As if enrollment reduction were not a big challenge by itself, loss of relevance of IS programs has quickly emerged as another big challenge. Throughout thirty five years of experience as an academic as well as an industry consultant, I have seen Information System programs losing the border zones of its once traditional territory to closely related disciplines, like Information Technology and Computer Science on one side, and to business-domain disciplines, like Accounting, Finance, and Operations Management on the other side. An additional competition has come from vendor certifications. We have been quietly enclosed into a limited dominion.

Even more important is that IS academics are not perceived as relevant by IS practitioners, so they usually don't come to us for help with their problems. Regarding technical needs, they usually go to hardware vendors, software developers, and providers of data communication services and equipment. And regarding implementation and systems integration services, which is probably our main dominion, they go to big consulting firms. "If the people who practice what we teach do not value what we are doing or saying, we will ultimately disappear." [10, 7].

\section{Other challenges}

Besides enrollment reduction and loss of relevance, we also face other challenges as well, which we will classify in the following three categories:

Industry-trend challenges. Industry trend challenges provoke big changes in the nature and procurement of the technological resources used by IS programs, as well as in the technical skills these programs have to develop in its students. Examples of challenges in this category are the outsourcing and offshoring movement, the cloud computing and virtualization trends, the commoditization of IS resources, and the competition from vendor certifications. Some of these challenges, like outsourcing and offshoring, arise from changes in the procurement of IS/IT resources. Others, like cloud computing, virtualization, and the commoditization of IS resources, arise mostly from technological changes. An additional example of these challenges is the surge in industry certifications, which on one hand evidences the need for specialized knowledge and skills, and on the other hand evidences a proactive action from industry representatives to quickly procure people with specific skills and knowledge [8].

There is not much we can do about industry-trend challenges, except adapting to them. Fast technology changes will continue to happen, together with changes in the approaches used to procure technological resources. We have to adapt to these challenges the best we can, within the budget constraints of our institutions.

Perception-related challenges. These challenges represent a very important category, as we live in a society where perception easily becomes reality, or at least, has similar implications.

On one side, we have the perception from students, academic advisors and counselors, who believe that "...only nerdy "non-cool" geeks are involved" in IS [11], and that "We lack the cool factor. ... The technology may be cool, but those who work in it are decidedly not" [20].

On another side, the IS field faces an identity problem. Many people don't really understand what Information Systems is. They may be somewhat clear that Information Technology relates to technological infrastructure, and Computer Science relates to programming. We have probably heard questions like "What is IS?" or "Isn't IS the same as IT and CS?". And if we try to establish a difference by explaining that IS deals with the environment in which technology works, they then ask: "But isn't that what Accounting, Marketing and Finance do?" [7].

Parent perception about the IS field is also very important, as they usually have a big influence over students decisions regarding what to study in college. Many parents believe that technology jobs are moving offshore. "Outsourcing is also the unspoken cause of many potential students not majoring because they assume all domestic IS jobs will disappear." [12]. But the real fact is that job opportunities continue to rise, as well as salaries and employee satisfaction [16]. 


\section{Issues in Information Systems}

Volume 14, Issue 2, pp.101-108, 2013

Although we cannot fully control perception-related challenges, we can certainly do a lot to influence them.

Internal challenges. We are also facing challenges intrinsic to our IS programs. On one side, employers are asking for a wider set of skills in our graduates, ranging from functional knowledge to technical skills, and, of course, without leaving out "soft skills", like teamwork, communications ability, ethical values and interpersonal relationships. [7, 5, 11]. It is certainly a challenge to develop and implement an IS curriculum that can stress enough on all these skills and at the same time comply with restrictions and regulations imposed by our institutions, local authorities and accreditation agencies.

On the other side, students and employers are asking for a change in the educational strategies we have been using for decades. The traditional approach has been lecture and hands-on laboratories. [9]. IS programs may be best served by integrating business functional knowledge and teaching through experiential learning models [1]. Experiential learning can be defined as "education that occurs as a direct participation in the events of life" [13]. It involves a "direct encounter with the phenomena being studied rather than simply thinking about the encounter, or only considering the possibility of doing something about it." [4]. Students learn by experiencing rather than simply listening. Case studies based on real or simulated, but meaningful, situations, as well as team projects and industry interaction are ways for implementing this kind of learning [9].

The good thing about internal challenges is that we can fully control them, even though we still have to comply with institutional restrictions, which may dilute our level of control. And not only we can control them, but by doing it we have a good opportunity to influence other type of challenges, particularly those related to perception.

Based on the previous discussion, it should be clear that IS programs are facing big challenges and that we must do something about them. While doing this, we must focus on internal challenges, which are the ones over which we have the highest level of control. Let's see now what we propose.

\section{A proposal to address internal challenges: redefine educational strategies and skill set in IS programs}

In order to tackle internal challenges, we specifically propose two strategies: (1) To offer a functionally integrated curriculum and deliver it through an experiential educational strategy, like Project Based Learning, and (2) To continuously analyze the skill set that we are developing in our students around the specific market that we want to serve, and to redefine this set accordingly.

\section{PROJECT-BASED LEARNING (PBL)}

\section{A brief description of PBL}

Project-Based Learning is an experiential learning model that promotes collaborative versus isolated learning, active (hands on) versus passive learning and integrated versus fragmented learning. It emphasizes applied versus theoretical learning, high-order thinking versus plain comprehension, and a wide range of skills, including technical, managerial and soft skills. [3, 1, 15].

\section{PBL versus PBL}

The PBL acronym is sometimes used indistinctively for "Project-Based Learning" as well as "Problem-Based Learning", maybe because both strategies include problem analysis, solution design and solution implementation. Although they share many things in common, they are not exactly the same. The difference seems to be more in the emphasis, not in the concept. "Problem-Based Learning" tends to be more oriented towards problem analysis, while "Project-Based Learning" tends to be more oriented towards design and implementation. [21]. For our purposes, the important thing is that both of them include problem analysis, solution design and solution implementation, regardless of the particular emphasis of each one. 


\section{Issues in Information Systems}

Volume 14, Issue 2, pp.101-108, 2013

\section{PBL models}

There are several models which can be used to implement PBL within an academic program, some of them being used for decades [1]. Table 1 presents some of them. Notice that they are not mutually exclusive. That is, several of them can be combined within a given academic program.

Table 1: PBL models

\begin{tabular}{|l|l|}
\hline$\#$ & Model \\
\hline 1 & Individual course projects versus (one) program capstone project \\
\hline 2 & One semester versus multi semester projects \\
\hline 3 & One course versus multi-course projects \\
\hline 4 & The professional school model (as used in Medical, Law, and/or Engineering schools) \\
\hline 5 & Industry sponsored and/or mentored projects \\
\hline
\end{tabular}

\section{A PBL IMPLEMENTATION: THE UPR CASE}

At the Computer Information Systems program of the University of Puerto Rico (UPR) we have used some form of Project-Based Learning (PBL) for a long time, but in the last several years we have formally embedded this strategy into a new curricular design. We are using PBL as an educational strategy to enable the achievement of our student outcomes, and also as an assessment strategy to measure outcome attainment as a byproduct of the enabling process.

\section{PBL implementation methodology}

To implement PBL, we created an Assessment Committee consisting of several faculty members. The committee used the following five-step methodology (see Table 2). The committee assumed ultimate responsibility for all steps, but delegated some of them to the professors in charge of the courses.

Table 2: Methodology used to implement PBL

\begin{tabular}{|l|l|l|}
\hline$\#$ & Steps & Brief description \\
\hline 1 & Identifying typical IS projects & $\begin{array}{l}\text { Identify typical IS projects performed by IS } \\
\text { professionals. Input from students, alumni, employers } \\
\text { and Advisory Board should be obtained. }\end{array}$ \\
\hline 2 & Embedding projects into the curriculum & $\begin{array}{l}\text { Embed the previously identified projects into the } \\
\text { curriculum by assigning to each course a project where } \\
\text { students have the opportunity to integrate the knowledge } \\
\text { acquired and to develop the required skills. When } \\
\text { necessary, create new courses to accommodate projects. } \\
\text { Make sure projects are aligned to student outcomes. }\end{array}$ \\
\hline 3 & $\begin{array}{l}\text { Creating cases and/or situations related } \\
\text { to the projects }\end{array}$ & $\begin{array}{l}\text { Create cases or situations upon which the projects are } \\
\text { developed. Put a lot of attention to make sure the } \\
\text { projects resulting from these cases or situations are } \\
\text { comprehensive and meaningful enough to allow students } \\
\text { to apply most knowledge obtained and skills developed in } \\
\text { the course, but at the same time manageable enough for a } \\
\text { one semester course. Cases and project descriptions } \\
\text { should be prepared by professors, but reviewed and } \\
\text { approved by the Assessment Committee. }\end{array}$ \\
\hline 4 & $\begin{array}{l}\text { Assessing the attainment of student } \\
\text { outcomes through the projects }\end{array}$ & $\begin{array}{l}\text { Assess student projects to determine the extent to which } \\
\text { student work attained the student outcomes supported by } \\
\text { the project. Project assessment can be delegated to the } \\
\text { professors teaching the courses, but using standard } \\
\text { rubrics prepared by the Assessment Committee. }\end{array}$ \\
\hline
\end{tabular}




\begin{tabular}{|l|l|l|}
\hline$\#$ & Steps & Brief description \\
\hline 5 & Controlling quality of the process & $\begin{array}{l}\text { Quality must be controlled throughout all steps by several } \\
\text { means. One of them is requiring students to make oral } \\
\text { presentations to the professor. Other quality control } \\
\text { measures are the use of a standard rubric for each project } \\
\text { and the use of an automated tool to facilitate data } \\
\text { collection and calculations. The rubrics, as well as the } \\
\text { data collection tool, should be prepared by the } \\
\text { Assessment Committee. Students should be encouraged } \\
\text { to prepare project portfolios and to participate in poster } \\
\text { sessions. }\end{array}$ \\
\hline
\end{tabular}

In a separate paper we will present the results of the use of this methodology to implement PBL, both as an educational and as an assessment strategy. The paper includes the research methodology used, the discussion of results, and the conclusions and best practices derived from the research.

\section{ANALYZING AND REDEFINING AN IS PROGRAM SKILL SET}

Another strategy that we propose to tackle IS program internal challenges are the analysis and redefinition of the skill set being developed in students. There has been "...a shift in the mission of the IS function from providing technology-based solutions to managing the process of delivering and providing them..." [1], both in firms providing technological resources (IT vendors) and firms implementing and using those resources (IT clients). As a result, the desired skills for IS graduates have been moving towards client-facing skills, like project management, systems analysis, and business domain knowledge, over technical skills. This shift makes it necessary to analyze the skill set we are developing in our students and to redefine it around the market that we want to serve. Other factors, like technological developments and changes in the way IS/IT resources are procured, also justify this analysis.

\section{Market to be served: IT vendors, IT clients or both?}

To analyze and redefine the skill set, we must first define which market our program will serve. That is, IT vendors, IT clients or, if feasible, both markets.

To properly define the market our program will serve, and the skill set to emphasize, several points need to be considered [5]. These points are stated as questions in Table 3 .

Table 3: Points to consider when redefining the skill set

\begin{tabular}{|l|l|}
\hline$\#$ & Points to be considered \\
\hline 1 & Should we try to prepare programmers as Computer Science programs do? \\
\hline 2 & $\begin{array}{l}\text { Should we try to prepare infrastructure specialists (i.e. LAN managers, technical support specialists) } \\
\text { as Information Technology programs or vendor certifications do? }\end{array}$ \\
\hline 3 & Should we try to prepare business analysts as Accounting or Finance programs do? \\
\hline 4 & $\begin{array}{l}\text { How should we address the competition from big consulting firms, some of which have their own } \\
\text { professional development programs conducted by industry, systems and technical experts? }\end{array}$ \\
\hline 5 & How much should we emphasize systems analysis and project management skills? \\
\hline 6 & How many firms recruit systems analysts and project managers for entry-level positions? \\
\hline 7 & $\begin{array}{l}\text { Are we going to survive and grow as a discipline preparing students mostly for non-entry-level } \\
\text { positions? }\end{array}$ \\
\hline
\end{tabular}




\section{AN IMPLEMENTATION OF A SKILL-SET ANALYSIS AND REDEFINITION: THE UPR CASE}

As stated before, at the Computer Information Systems program of the University of Puerto Rico (UPR) we redesigned the curriculum around PBL, using projects closely resembling those performed by IS professionals as the departing point. The reasoning behind this was that meaningful and well-chosen projects, should allow students to develop and integrate a comprehensive set of skills, including technical, functional and soft skills. Since projects constitute a larger building block than skills, it was easier to identify them, and to align them with our student outcomes, educational objectives and mission.

Even though so far the PBL implementation has been successful, we want to validate that the program design has not excluded, over-emphasized or under-emphasized important skills for the market we want to serve. We are performing this validation process through a skill-set analysis.

\section{Implementation methodology}

To implement the skill set analysis, we followed the seven-step methodology included in Table 4. After we defined the market our program will serve, we then defined the skills required by that market, mapped them to our curricula, identified gaps and modified curricula accordingly. While doing this, we kept in mind the degree to which we wanted to stress technical skills, like programming and technical support, or client-facing skills, like systems analysis, process modeling and project management.

Table 4: Methodology to implement a skill set analysis and redefinition

\begin{tabular}{|c|c|c|}
\hline \# & Steps & Brief description \\
\hline 1 & $\begin{array}{l}\text { Decide on the market the IS program will } \\
\text { serve (IT vendors, IT clients, or both) }\end{array}$ & $\begin{array}{l}\text { Based on the points included in Table } 3 \text {, decide on the } \\
\text { specific market to be served, and choose the skill set } \\
\text { most suitable for that market. }\end{array}$ \\
\hline 2 & $\begin{array}{l}\text { Prepare a skills inventory for that market } \\
\text { (technical skills, client-facing skills, or } \\
\text { both) }\end{array}$ & $\begin{array}{l}\text { Prepare an inventory of skills ranging from client-facing } \\
\text { to the more technical ones, without leaving out soft- } \\
\text { skills. Professional publications, as well as input from } \\
\text { students, alumni, and employers, should be taken into } \\
\text { consideration. Due to the large set of skills that may } \\
\text { result, consider defining first major skill categories } \\
\text { following systems life-cycle phases (analysis, logical } \\
\text { design, physical design, implementation, etc.), as well as } \\
\text { systems operation tasks. Identify then more detailed } \\
\text { skills, within each major category. }\end{array}$ \\
\hline 3 & $\begin{array}{l}\text { Perform a mapping of skills to current } \\
\text { curriculum }\end{array}$ & $\begin{array}{l}\text { Map the skills for the market to be served to the skills } \\
\text { being developed in the program. While performing this } \\
\text { mapping, take into consideration assignments and } \\
\text { project descriptions, besides course contents. }\end{array}$ \\
\hline 4 & $\begin{array}{l}\text { Identify gaps (skills not addressed or not } \\
\text { addressed enough) }\end{array}$ & $\begin{array}{l}\text { As a result of the previous mapping, identify gaps } \\
\text { between the desired skill set and the actual skill set } \\
\text { being developed. That is, skills excluded, over- } \\
\text { emphasized or under-emphasized. }\end{array}$ \\
\hline 5 & $\begin{array}{l}\text { Modify course content in order to fill the } \\
\text { gaps previously identified. }\end{array}$ & $\begin{array}{l}\text { Modify current courses to add, delete, and change } \\
\text { emphasis of the currently supported skills. }\end{array}$ \\
\hline
\end{tabular}




\begin{tabular}{|l|l|l|}
\hline$\#$ & Steps & Brief description \\
\hline 6 & Add and/or delete full courses as needed & $\begin{array}{l}\text { Add new courses and/or delete current courses in order } \\
\text { to fill the gaps not taken care through the modification } \\
\text { of courses. }\end{array}$ \\
\hline 7 & $\begin{array}{l}\text { Redesign assessment methods and } \\
\text { modify rubrics accordingly }\end{array}$ & $\begin{array}{l}\text { Redesign assessment methods as necessary to make sure } \\
\text { they support the desired skill set. Modify rubrics } \\
\text { according to the redesign of these methods. }\end{array}$ \\
\hline
\end{tabular}

A separate paper will present in more detail the implementation methodology used, the discussion of results, and the conclusions and best practices derived from this validation project.

\section{ACKNOWLEDGEMENTS}

The author wants to acknowledge the support from his colleagues in the IS Department, particularly those belonging to the Assessment Committee. A special acknowledgement and appreciation to Dr. Pedro RodríguezEsquerdo, IS Department head, and Prof. María del Rosario Rodríguez-Orellana, IS major coordinator, for reviewing the draft of this paper and making thorough recommendations to improve it.

\section{REFERENCES}

1. Abraham, Thomas; Beath, Cynthia; Bullen, Christine; Gallagher, Kevin; Goles, Tim; Kaiser, Kate; and Simon, Judith (2006). "IT Workforce Trends: Implications For IS Programs", Communications of the Association for Information Systems: Vol. 17, Article 50. Available at: http://aisel.aisnet.org/cais/vol17/iss1/50

2. ACM and AIS (2010). IS 2010: Curriculum Guidelines for Undergraduate Degree Programs in Information Systems. Available at http://www.acm.org/education/curricula

3. Anderson-Cruz, Helen and Gretchen N. Vik. (2007). Using Project-Based Learning to Connect Theory to Practice in Teaching Accounting Communication, Proceedings of the 2007 Association for Business Communication Annual Convention

4. Borzak, L. (1981) (ed) Field study: A Source Book for Experiential Learning. Beverly Hills; Sage

5. Bullen, Christine V.; Abraham, Thomas; Gallagher, Kevin; Simon, Judith C.; and Zwieg, Phil (2009). "IT Workforce Trends: Implications for Curriculum and Hiring", Communications of the Association for Information Systems, Volume 24, Article 9, pp. 129-140, January 2009, Retrieved from http://aisel.aisnet.org

6. DICE Tech Salary Survey Results. (2012). Dice Holdings, Inc., www.dice.com

7. Firth, David; King, John; Koch, Hope; Looney, Clayton Arlen; Pavlou, Paul; and Trauth, Eileen M. (2011) "Addressing the Credibility Crisis in IS," Communications of the Association for Information Systems: Vol. 28, Article 13. Available at: http://aisel.aisnet.org/cais/vol28/iss1/13

8. Future of Computing in Education Position Papers (2009). Association for Computing Machinery. Available at http://www.acm.org/education/future-of-computing-education-summit/position-papers/Comptia.pdf

9. Future of Computing in Education Summit (2009). Association for Computing Machinery. Available at http://www.acm.org/education/future-of-computing-education-summit

10. Ginzberg, Michael J. (2012). A Business Dean's Perspective on the IS Field, The DATA BASE for Advances in Information Systems, Volume 43, Number 2, May 2012

11. Granger, Mary J.; Dick, Geoffrey; Luftman, Jerry; Van Slyke, Craig; and Watson, Richard T. (2007). "Information Systems Enrollments: Can They Be Increased?,"Communications of the Association for Information Systems: Vol. 20, Article 41. Available at: http://aisel.aisnet.org/cais/vol20/iss1/41

12. Gray, Paul. (2012). The Other?, The DATA BASE for Advances in Information Systems Volume 43, Number 2, May 2012

13. Houle, C. (1980). Continuing Learning in the Professions, San Francisco, CA; Jossey-Bass Publishers

14. Koch, Hope; Van Slyke, Craig; Watson, Rick; Wells, John; and Wilson, Rick (2010). "Best Practices for Increasing IS Enrollment: A Program Perspective," Communications of the Association for Information Systems: Vol. 26, Article 22. Available at: http://aisel.aisnet.org/cais/vol26/iss1/22

15. Kolb, D. A. (1984). Experiential Learning: Experience as the Source of Learning and Development. Englewood Cliffs, N.J.: Prentice-Hall, Inc. 


\section{Issues in Information Systems}

Volume 14, Issue 2, pp.101-108, 2013

16. Laudon, K (2011). Occupational and Career Outlook for MIS Majors 2012-2018, Creative Commons, New York University Stern School of Business

17. McDowell, C., Werner, L., Bullock, H., \& Fernald, J. (2006). Pair programming improves student retention, confidence, and program quality. Communication of the ACM, 49(2), 90-95. Retrieved March 7, 2009 from ACM digital library http://www.acm.org/dl

18. Savery, John R. (2006). Overview of Problem-based Learning: Definitions and Distinctions, The Interdisciplinary Journal of Problem-based Learning, volume 1, no. 1

19. Tamiru, Mohan (2012). Should IS Departments Have a Strong Presence in the Business School?, The DATA BASE for Advances in Information Systems Volume 43, Number 2, May 2012,

20. Todd, Peter (2012). What are They Thinking...A View the IS Field "from the Dean's Office", The DATA BASE for Advances in Information Systems Volume 43, Number 2, May 2012

21. University of Oregon (n.d.). "Problem-Based Learning and Project-Based Learning", Available at http://pages.uoregon.edu/moursund/Math/pbl.htm

22. Zweben, Stuart (2011). Computing Degree and Enrollment Trends, Computing Research Association, Retrieved from http://cra.org 